\begin{tabular}{|c|c|}
\hline Improsts & 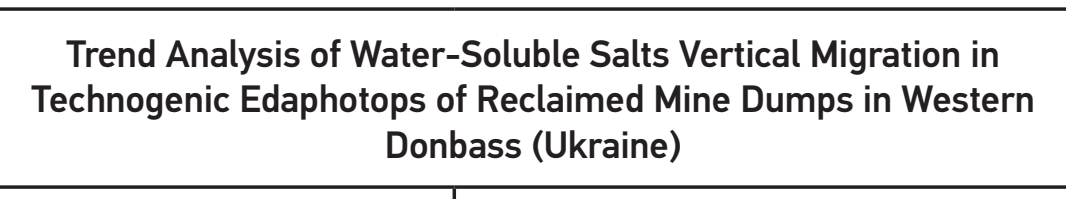 \\
\hline & 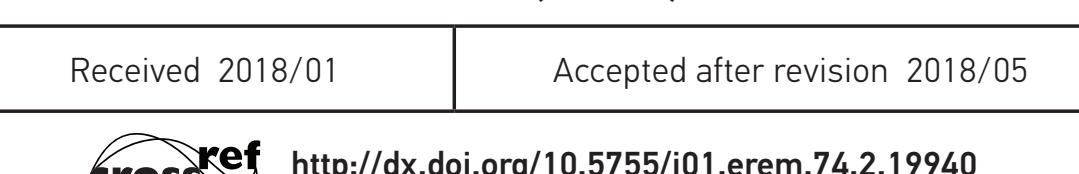 \\
\hline abass & $\begin{array}{l}\text { ysis of Water-Soluble } \\
\text { al Migration in } \\
\text { ic Edaphotops of } \\
\text { Mine Dumps in Western } \\
\text { Jkraine) }\end{array}$ \\
\hline
\end{tabular}

\title{
Iryna Klimkina
}

State Higher Educational Institution “National Mining University”, 49005, Dmytro Yavornytskiy Av. 19, Dnipro, Ukraine

\section{Mykola Kharytonov}

Dnipropetrovsk State Agrarian and Economic University, S.Yephremova Street, 25, 49600, Dnipro, Ukraine

\section{Oleksandr Zhukov}

Oles Honchar Dnipro National University, Gagarin Av.72, 49010, Dnipro, Ukraine

\section{Corresponding author: irina_klimkina@ukr.net}

I. Klimkina, State Higher Educational Institution “National Mining University”,

49005, Dmytro Yavornytskiy Av. 19, Dnipro, Ukraine

Surface evaporation rates that are greater than precipitation rates lead to upward salinization processes and, consequently, man-made contamination of the covering surface layers on coal dumps in Western Donbass, Ukraine. The effectiveness of capping the mine dumps with different layers of black-soil mass, both with and without a shielding layer of loess-like loam, was studied in order to develop the optimal scheme for the reclamation of these dumps. Principal component analyses were carried out in order to reveal the regularities of the upward salt migration to the surfaces of reclaimed coal mine dumps. The parameters of the layer-by-layer variation of the physical and chemical data in soil water extracts (namely, $\mathrm{pH}$, total salinity and concentrations of bicarbonates, chlorides, sulfates, calcium, magnesium, sodium and potassium) which were obtained in 1987, 2003 and 2016 along the reclaimed profiles of various models of technogenic edaphotop, gradually acquire a stable-equilibrium state of mineralization in space and time. The alkaline barrier is the main factor for $\mathrm{pH}$-changes and profile salinization of reclaimed land.

Keywords: mine dump reclamation, water-soluble salts migration, soil profile, principal component analysis. 


\section{Introduction}

The need for land reclamation in Ukraine's Western Donbass region is associated with the long-term underground coal development in the Samara River floodplain. The problems associated with environmental restoration after coal mining are relevant even for such developed countries as USA, Germany, UK and others (Chugh and Behum 2014; Bellenfant et al. 2013; Wiessner et al. 2013; Lottermoser 2010; Bian Zhengfu et al. 2010). However, the difference in the ratio of precipitation and evaporation can exclude the automatic application of known reclamation approaches and so requires the development of new technologies for application in Ukraine.

The problem of nature conservation in Western Donbass is very real since almost half of the coal reserves are deposited under Samara River floodplain and its tributaries. Among the negative impacts after coal mining, contamination of surface and groundwater bodies is the most significant. The main sources of such contamination (that is, besides the mine water from beneficiation plant) are the mine-tailing dumps and products resulting from coal dressing. The coal mining also results in the formation of deep fissures and intense subsidence on the floodplain surface (up to $1 \mathrm{~m}$, and sometimes up to 3-7 m). The areas of subsidence are then filled with ground and surface water and turn into a waterlogged reservoirs, leading to subsidence at the surface and, eventually, to the flooding of large areas. The environmental state is aggravated by leaching toxic substances from waste rocks accumulated in slag heaps, which contaminates soils and groundwater (Yevgrashkina et al. 2009).

Reclamation of these floodplain areas has been carried out for almost 50 years using rocks from mine excavation. This may result in the extraction of environmentally hazardous substances at critical concentrations in soils and surface waters (Kostenko and Opanasenko 2005; Kharytonov et al. 2012). In that regard, environmentally harmful substances in mine dumps (such as sulfides and chlorides) vary over time, depending on the physical and chemical conditions (Kharytonov and Yevgrashkina 2009).

At the initial stage of weathering, leaching of water-soluble salts from mine-dump rocks is observed, a process that begins almost immediately after placing the mine rocks at surface level. With the passage of time, the rate of salt removal decreases, and such trends contribute to the improvement of the dumps in terms of their reclamation. The rate of salt removal depends on several factors, such as geomorphological conditions of excavation, the texture and chemical composition of mine rocks, and bioclimatic potential. However, the rate of change in the chemical rock composition can be different, and the main source of harmful chemical influence is sulfides (such as pyrite, pyrrhotite, and marcasite) which, after oxidation, turn into iron sulfate and sulfuric acid (Kharytonov and Yevgrashkina 2009; Hayes et al. 2014; Huff 2014).

The main environmental challenge in developing the optimal scheme for land reclamation in Western Donbass is the prevention of upward salinization and consequent man-made contamination of overlying artificial surfaces which results from the rate of evaporation being greater than the infiltration rate from rainfall precipitation (Kharytonov 2007; Tarika and Zabaluev 2004; Konhke 1950). This imbalance is the most important factor in enhancing the weathering of potentially toxic rocks accumulated in mine dumps. An earlier assessment of the qualitative and quantitative composition of the anions and cations in aqueous extractions from soil and rock samples showed that the main unacceptable consequence is the gradual salinization of the artificial surface layers of reclaimed lands with sodium and magnesium chlorides and sulfates contained in coal dumps (Kharytonov and Kroik 2011; Bender 1983).

Thus, the majority of mine dumps requires measures for protecting the upper layer from the accumulation of toxic salts resulting from their upward migration. For example, high levels of exchangeable aluminum are considered to be the main restriction for plant growth (Shengyin Wang et al. 2016; Silva 2012), and to neutralize this effect it is recommended that chemical ameliorants are applied so as to create geochemical barriers (José Roberto Pinto de Souza et al. 2000). In addition, several methods for land reclamation have been proposed, such as application of various calcium-containing substances (such as lime) (Nkongolo et al. 2016), 
fly coal ash (Malik and Thapliyal 2009; Zhenqi Hu et al. 2004), sludge from alumina processing (Kyncl 2008), increased amounts of organic matter (such as sewage sludge and compost) (Baran et al. 2015; Tamanini et al. 2008; Larney and Angers 2012) and mineral fertilizers (Sheoran et al. 2010), plus the imposition of a layer of carbonate rocks (Hoff and Kolff 2012).

Observations of the mine dumps in Western Donbass indicate the need to study the changes in physicochemical properties of the mine rocks, establish the rate of removal of the weathered rock material, and study the vertical migration of toxic substances along the technogenic edaphotop of the reclaimed land. Thus, experiments suggested a long-term study of the effectiveness of the two- and three-layer reclamation models as geochemical barriers for blocking the upward migration of toxic salts from the mine dumps.

Considering the above-mentioned issues, the goal of the presented study was to identify the regularity, or otherwise, of patterns in the leaching of soluble salts along the profile, and the dynamics of these processes over time, depending on the initial designs of the soil-like bodies at the reclaimed mine dumps.

\section{Materials and methods}

The presented study was conducted on the basis of the Pavlograd experimental station for reclamation of disturbed lands in Western Donbass (eastern Ukraine) located nearly mine "Pavlogradska" (coordinates $48^{\circ} 33^{\prime} 24^{\prime \prime}$ N, $35^{\circ} 58^{\prime} 46^{\prime \prime}$ E). The station was founded in 1976 in the floodplain of the Samara River in order to examine the best restoration measures.

The "Pavlogradska" mine was put into operation in 1968 with the project capacity of 1200 thousands ton per year. The project capacity was reached at 1977. Industrial field of the mine is located in the floodplain of Samara river in Dnipropetrovsk region.

The main reclamation objective included the cultivation of both field and orchard crops. The scheme for reclamation of disturbed land was based on the study of the effectiveness of capping the mine dumps with different layers of black-soil mass (chernozem) both with and without a shielding layer of loess- like loam.
In this study the following models (variants) of technogenic edaphotops were used to look into the peculiarity of upward migration of toxic salts from the mine dumps:

1 Mine rock (MR) $+30 \mathrm{~cm}$ of the bulk layer of black soil (30BS);

$2 \mathrm{MR}+50 \mathrm{BS}$;

$3 \mathrm{MR}+50 \mathrm{~cm}$ of the loess-like loam (50LLL) + 30BS;

$4 \mathrm{MR}+50 \mathrm{LLL}+50 \mathrm{BS}$.

The general scheme of artificial soil profiles creation is presented in Figure 2. It should be noted that in every year (until 1997) all normal variants of plants associated with field crop rotation were grown. Then, due to reformation of the industrial enterprise "Pavlogradvugillia", the experimental sites were under natural overgrowth (Fig. 1).

\section{Fig. 1}

General view of the experimental site

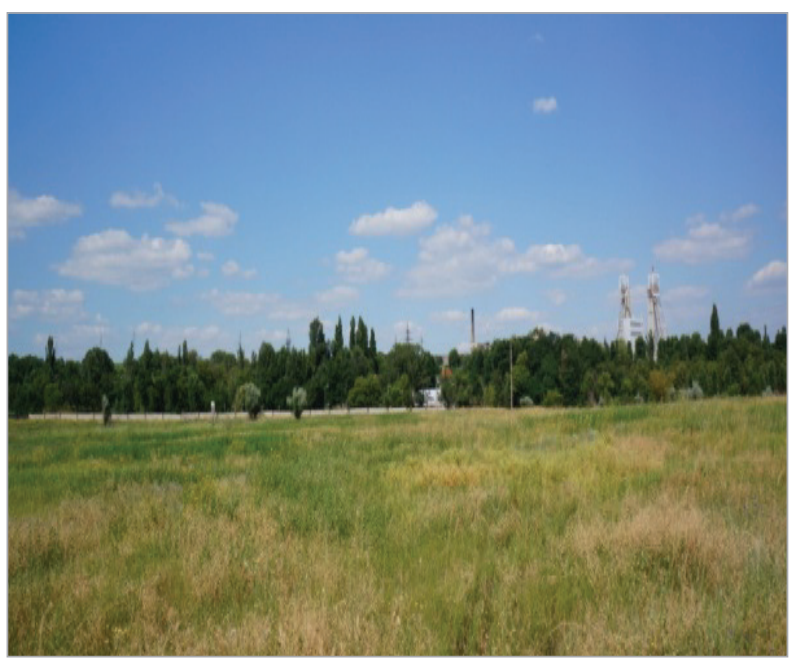

Fig. 2

The scheme of the experimental plots with 1-4 variants of reclamation

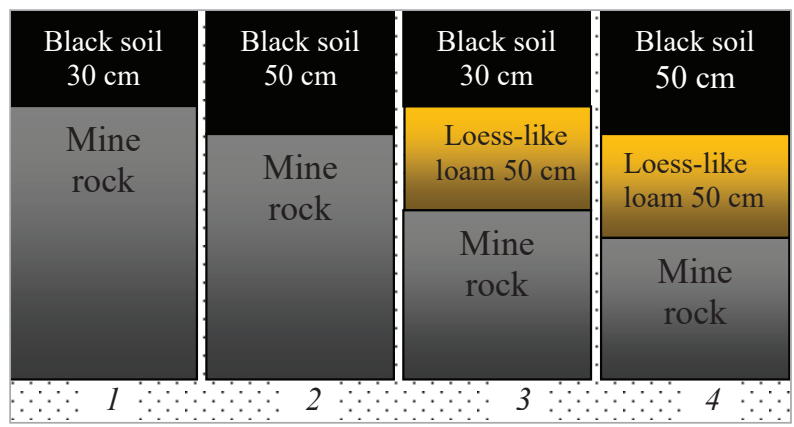


Samples of the soil substrates were collected at $10 \mathrm{~cm}$ depth intervals until the dump material was reached; these samples were then air-dried and sieved through a $2 \mathrm{~mm}$ screen for general analytical determinations. The $\mathrm{pH}$, conductivity and dry residue values were determined in accordance with the State Standard 26423-85 "Soils. Methods for determination of specific electric conductivity, $\mathrm{pH}$ and solid residue of water extract". Besides, concentrations of the following cations and anions were determined in accordance with commonly used techniques: bicarbonates, chlorides, sulfates, calcium, magnesium, sodium and potassium (the State Standards 26428-85, 26423-85, 2642685, 26425-85, 29269-91).

Statistical calculations were carried out using Statistica 7.0. Principal components analyses were applied in order to reveal the regularities of the upward salt migration along the overall surface of reclaimed coal mine dumps.

In the presented study the following factors were considered as the predictors:

the "type" of reclamation factor (factor levels: reclamation variants 1 (MR + 30BS), 2 (MR + 50BS), $3(\mathrm{MR}+50 \mathrm{LLL}+30 \mathrm{BS})$ and 4 (MR + 50LLL + 50BS);

the "time" factor (factor levels: 1987, 2003 and 2016 years of research);

the "depth" of sampling factor represented by data from each $10 \mathrm{~cm}$ of the soil substrate profile until dump material (factor levels: data of the physical and chemical analysis of the concentrations in soil water extracts, namely $\mathrm{pH}$, total salinity and concentrations of the bicarbonates, chlorides, sulfates, calcium, magnesium, sodium and potassium).

\section{Results and discussion}

The principal component analyses revealed three main components whose eigen values exceeded 1 ; in aggregate these account for $68.13 \%$ of total variance (Table 1).

The principal component 1 (PC1) accounts for $47.01 \%$ of total variance, and this component is characterized by statistically significant correlation coefficients with

\section{Table 1}

Principal component analyses of the variation related to the mineralization of soil solution and chemistry of water extraction (Note: Statistically significant correlation coefficients are given for $p<0.05$ )

\begin{tabular}{c|c|c|c}
\hline \multirow{2}{*}{ Variable } & \multicolumn{3}{|c}{ Principal components } \\
\cline { 2 - 4 } & $\mathrm{PC1}$ & $\mathrm{PC2}$ & $\mathrm{PC3}$ \\
\hline 1 & 2 & 3 & 4 \\
\hline $\mathrm{pH}$ & 0.86 & - & -0.30 \\
\hline Dry residue, \% & -0.97 & - & - \\
\hline $\mathrm{HCO}_{3}{ }^{-}$ & -0.73 & 0.28 & -0.29 \\
\hline $\mathrm{Cl}^{-}$ & -0.84 & - & -0.24 \\
\hline $\mathrm{SO}_{4}{ }^{2-}$ & -0.96 & -0.12 & - \\
\hline $\mathrm{Ca}^{2+}$ & -0.95 & - & 0.13 \\
\hline $\mathrm{Mg}^{2+}$ & -0.91 & -0.13 & - \\
\hline $\mathrm{Na}^{+}+\mathrm{K}^{+}$ & -0.89 & -0.16 & -0.19 \\
\hline$\% \mathrm{Total} \mathrm{variance}^{+}$ & 47.01 & 10.73 & 10.39 \\
\hline
\end{tabular}

all features under consideration. The acidity index of soil extract is characterized by a positive coefficient of correlation, in contrast to the other indicators which are characterized by a negative coefficient. Thus, the PC1 reflects the level of total mineralization of the soil solution, indicating that the increase in mineralization is associated with a decrease in $\mathrm{pH}$ values.

The general linear model of the effect of the type of technogenic edaphotop, in combination with time and depth of sampling, provides an explanation for $92 \%$ of the $P C 1$ variability (Table 2).

It should be noted that all studied predictors, and their combinations, proved to be statistically reliable predictors of the PC1. The highest value for variation of the PC1 is established for "type" of technogenic edaphotop and "depth" of sampling (Figure 3). Although "time" is a statistically reliable predictor, it plays an insignificant role in the $\mathrm{PC} 1$ variation. In general, predictor "time" can be described as one that changes insignificantly during the study period.

The highest general level of mineralization is established in variant 1 (i.e. MR + 30BS), a level a little bit lower is specific for variant 2 (i.e. MR $+50 B S$ ), and 


\section{Table 2}

General linear model of effect of technogenic edaphotop type, in combination with time and depth of sampling on the PC1 value $\left(R^{2}=0,92\right)$

\begin{tabular}{l|c|c|c|c|c}
\hline \multicolumn{1}{c|}{ Predictors } & Sum of squares & Degree of freedom & Mean Sum of squares & F-ratio & $p$ \\
\hline 1 & 2 & 3 & 4 & 739.94 & 0 \\
\hline Intercept & 739.94 & 1 & 132.04 & 244.48 & 0.00 \\
\hline Type & 396.11 & 3 & 4.40 & 8.14 & 0.00 \\
\hline Time & 8.79 & 2 & 908.05 & 1681.37 & 0.00 \\
\hline Depth & 908.05 & 1 & 1.23 & 2.29 & 0.00 \\
\hline Type*Time & 7.41 & 6 & 13.59 & 25.16 & 0.04 \\
\hline Type*Depth & 40.77 & 3 & 7.50 & 13.90 & 0.00 \\
\hline Time*Depth & 15.01 & 2 & 2.01 & 3.73 & 0.00 \\
\hline Type*Time*Depth & 12.08 & 6 & 0.54 & - & 0.00 \\
\hline Error & 191.18 & 354 & & - \\
\hline
\end{tabular}

\section{Fig. 3}

Main elements of variations of PCs $1-3$

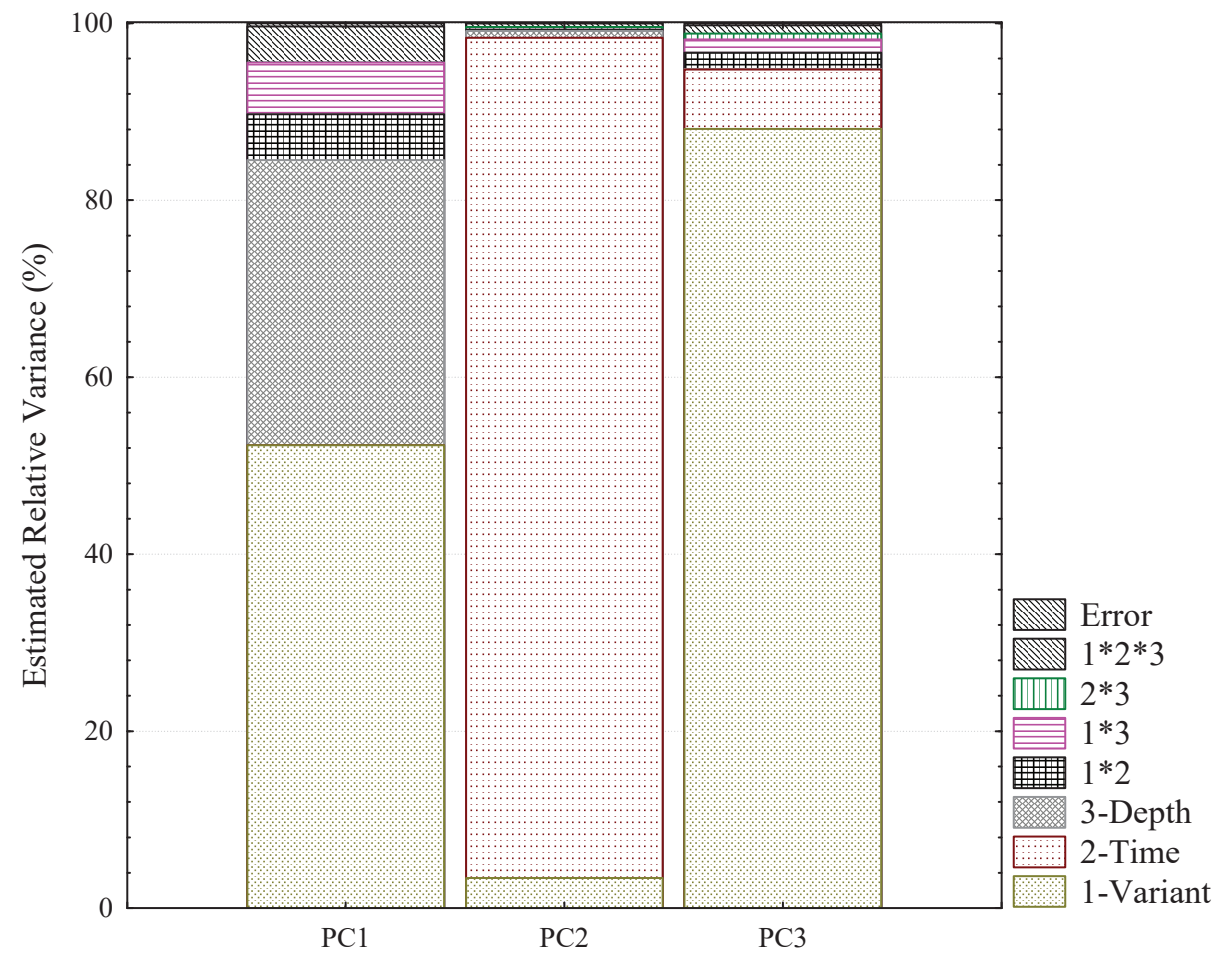


the lowest level of mineralization is more representative for variants 3 and 4 (i.e. MR + 50LLL + 30BS and $M R+50 L L L+50 B S$ respectively) (Figure 4).

Fig. 4

Variation of $\mathrm{PCl}$ depending on the type of technogenic edaphotop

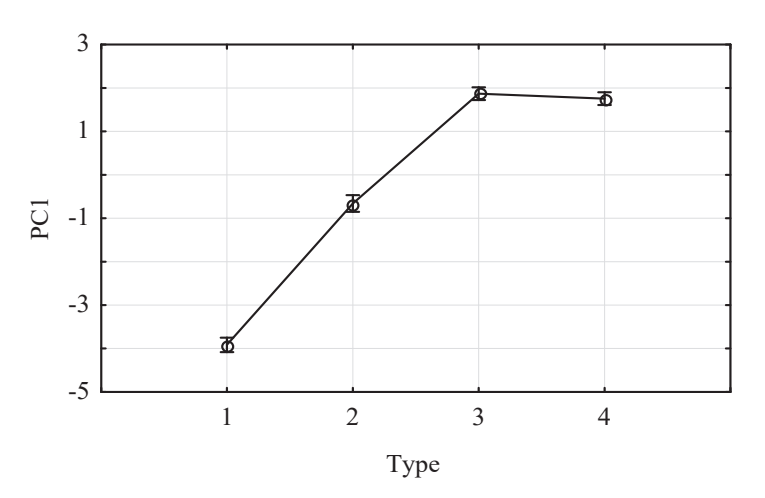

Conditional notations: 1 - variant 1 (MR + 30BS), 2 - variant 2 (MR + 50BS), 3 - variant $3(\mathrm{MR}+50 \mathrm{LLL}+30 \mathrm{mBS}), 4-$ variant 4 (MR + 50LLL + 50BS).
The profile distribution analysis of the $\mathrm{PC} 1$ values indicates the specificity of this feature depending on the type of technogenic edaphotop. Moreover, this index shows a certain invariance over time (Figure 5).

Thus, PC1 reflects the constitutional features of the profile distribution of the technogenic edaphotops properties. The general level of mineralization is sufficiently conservative feature, and its profile distribution is quite stably invariant over time. Similar behavior is observed for the distribution of general patterns of the water-soluble ions and $\mathrm{pH}$.

The principal component 2 (PC2) describes 10.73\% of the total variability. It positively correlates with the concentration of the hydrocarbonate ion and negatively with the concentration of the sulfate, magnesium and monovalent ions. It should be noted that the variation of these ions occurs under conditions of stable $\mathrm{pH}$ and stable mineralization of the soil solution (Table 3).

Fig. 5

Profile distribution of $\mathrm{PC} 1$ values depending on the type of technogenic edaphotop in different periods of the study
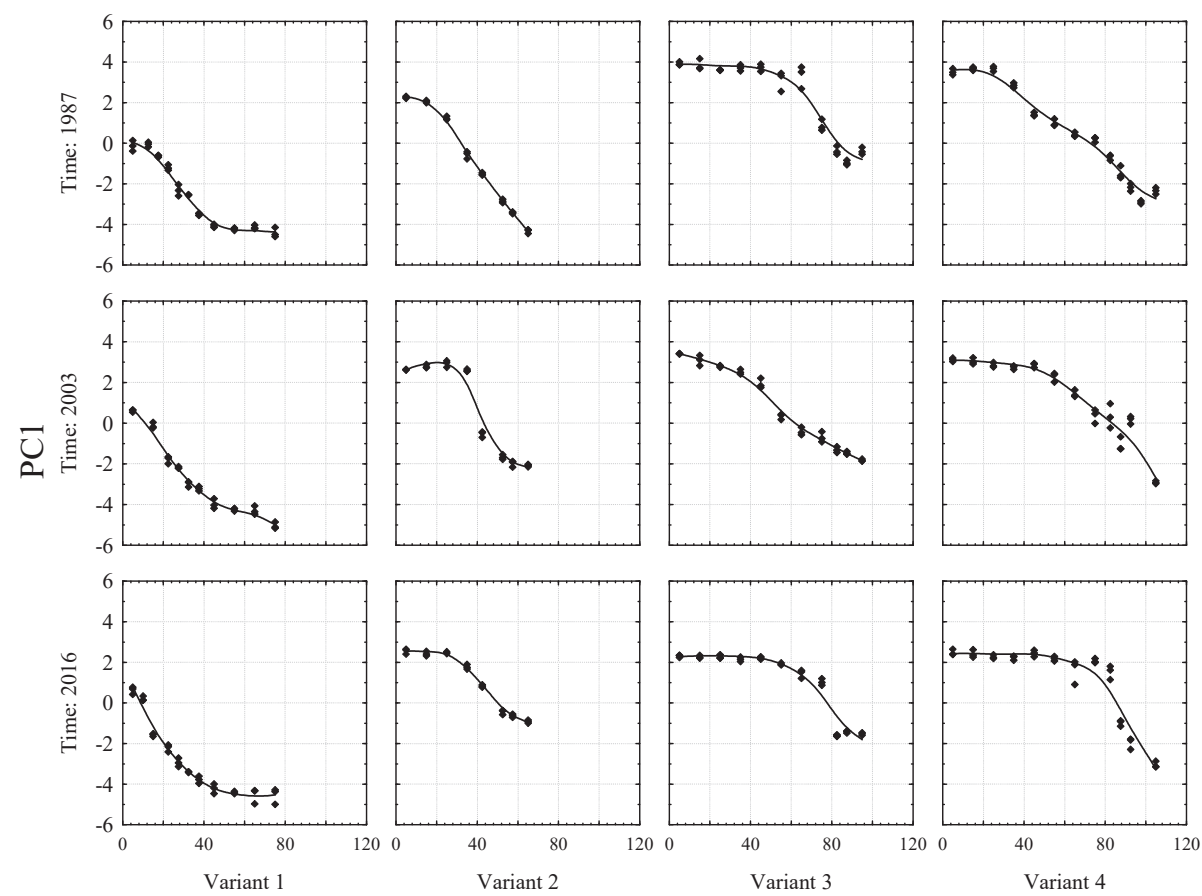

Depth 


\section{Table 3}

General linear model of effects of technogenic edaphotop type in combination with time and depth of sampling on the PC2 value $\left(R^{2}=0,99\right)$

\begin{tabular}{|c|c|c|c|c|c|}
\hline Predictors & Sum of squares & Degree of freedom & Mean Sum of squares & F-ratio & $p$-level \\
\hline 1 & 2 & 3 & 4 & 5 & 6 \\
\hline Intercept & 3.35 & 1 & 3.35 & 243.93 & 0.00 \\
\hline Type & 3.55 & 3 & 1.18 & 86.27 & 0.00 \\
\hline Time & 148.11 & 2 & 74.06 & 5396.96 & 0.00 \\
\hline Depth & 4.17 & 1 & 4.17 & 304.11 & 0.00 \\
\hline Type*Time & 0.28 & 6 & 0.05 & 3.38 & 0.00 \\
\hline Type*Depth & 0.33 & 3 & 0.11 & 7.99 & 0.00 \\
\hline Time*Depth & 1.30 & 2 & 0.65 & 47.29 & 0.00 \\
\hline Type*Time*Depth & 0.25 & 6 & 0.04 & 3.05 & 0.01 \\
\hline Error & 4.86 & 354 & 0.01 & - & - \\
\hline
\end{tabular}

External factors provide an explanation for $99.14 \%$ of the PC2 variation. All investigated predictors are statistically reliable, and the highest PC2 variation value is established for "time" (94.9\%). As shown in Figure 6 the PC2 value increases over time. The regression coefficient of depth has a negative sign $(-0.10 \pm 0.01)$, which indicates that the influence of the PC2 decreases with depth.

\section{Fig. 6}

Variation in PC2 over time

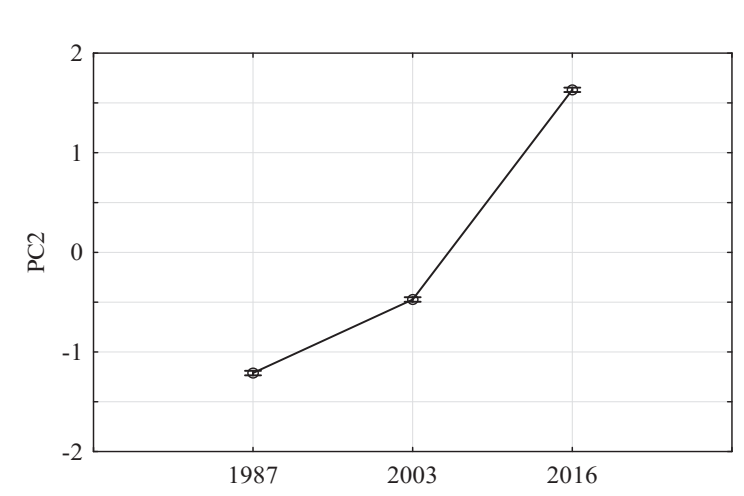

The peculiarities of the profile distribution variation of the PC2 values reflect the biogenic nature of this component, the value of which accumulates in time and attenuates with the depth of the soil layer (Figure 7).
Thus, the PC2 reflects the trend of an increasing content of hydrocarbonates and a reduction of sulfates, magnesium, potassium and sodium in the aqueous solution of soil extractions. This trend can be linked to the effects of the biogenic factor. Probably, the increase in the content of hydrocarbonates may occur due to the metabolic activity of the microbiota, which leads to a certain desalinization of the soil profile. Reclamation process usually requires huge amounts of water to provide desalinization from soil profile. It is imperative to know that leaching is not required until soil salinity exceeds the salt tolerance threshold of the crop (Gharaibeh et al. 2012). Musslewhite et al (2006) concluded that all weathered minesoils are expected to have little or no reduction in permeability based on established threshold EC and SAR relationship. Coversoil (e.g., topsoil) enhances remediation through physical and chemical buffering between sodic root-zone material and the reconstructed soil surface.

The principal component 3 (PC3) accounts for 10.39\% of the total variability. It correlates positively with the calcium content, and negatively with the $\mathrm{pH}$ value, as well as the content of hydrocarbonates, chlorines and monovalent ions. The general linear model of influence of the type of technogenic edaphotop, time, depth of sampling and their combination, explains $98 \%$ of the PC3 variability (Table 4 ). 
Fig. 7

Profile distribution of PC2 values depending on the type of technogenic edaphotop in different periods of the study
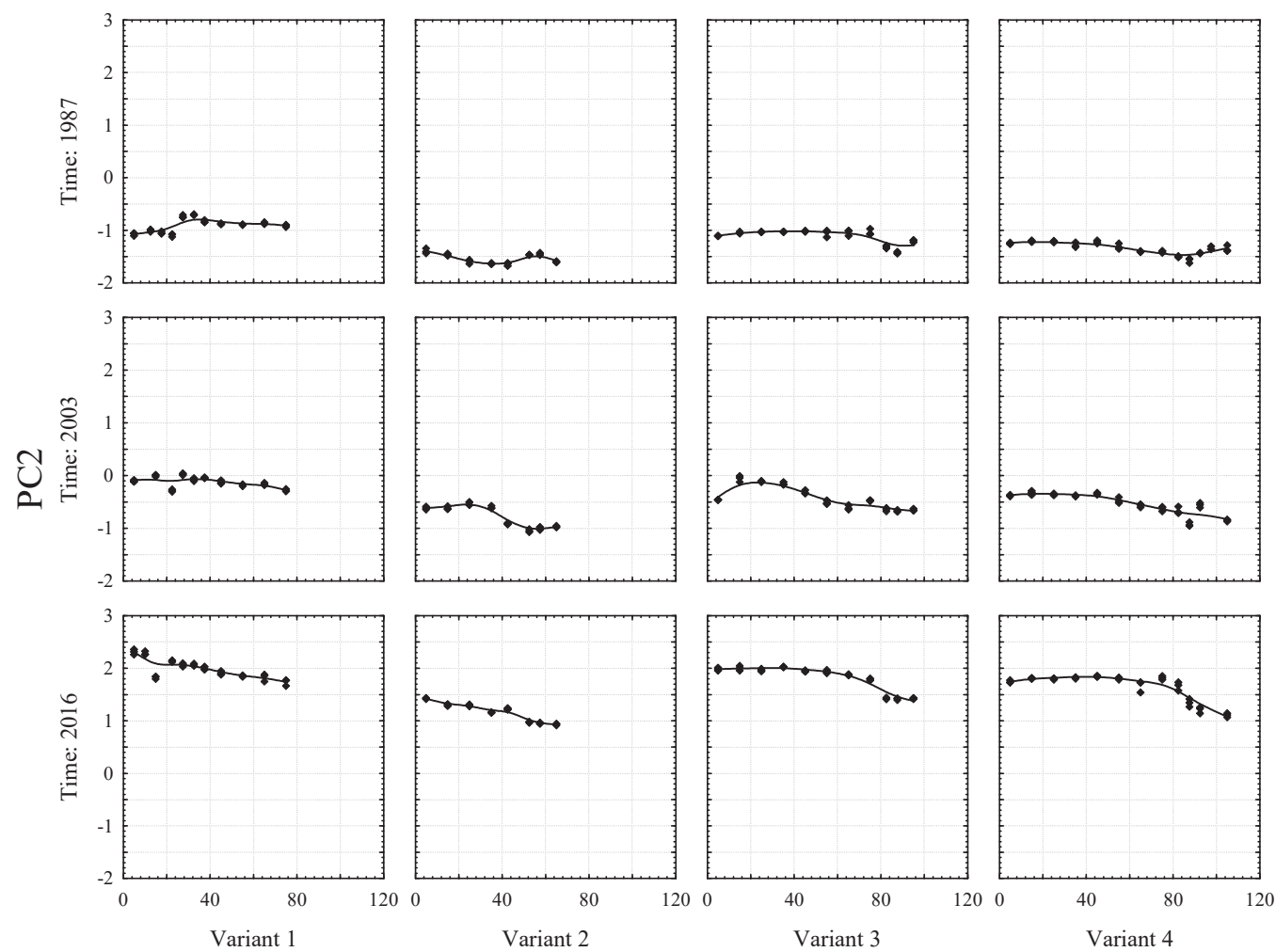

Depth

Table 4

General linear model of effect of technogenic edaphotop type in combination with time and depth of sampling on the PC3 value $\left(R^{2}=0,98\right)$

\begin{tabular}{l|c|c|c|c|c}
\hline \multicolumn{1}{c|}{ Predictors } & Sum of squares & Degree of freedom & Mean Sum of squares & $F$-ratio & $p$-level \\
\hline 1 & 2 & 3 & 4 & 5 \\
\hline Intercept & 1.42 & 1 & 1.42 & 38.95 & 0.00 \\
\hline Type & 74.60 & 3 & 24.87 & 683.24 & 0.00 \\
\hline Time & 6.80 & 2 & 3.40 & 93.40 & 0.00 \\
\hline Depth & 0.49 & 1 & 0.49 & 13.47 & 0.00 \\
\hline Type*Time & 1.09 & 6 & 0.18 & 5.01 & 0.00 \\
\hline Type*Depth & 8.07 & 3 & 2.69 & 73.87 & 0.00 \\
\hline Time*Depth & 2.51 & 2 & 1.26 & 34.55 & 0.00 \\
\hline Type*Time*Depth & 1.67 & 6 & 0.28 & 7.65 & 0.00 \\
\hline Error & 12.88 & 354 & 0.04 & -
\end{tabular}


Fig. 8

Dependence of PC3 on type of technogenic edaphotop and time

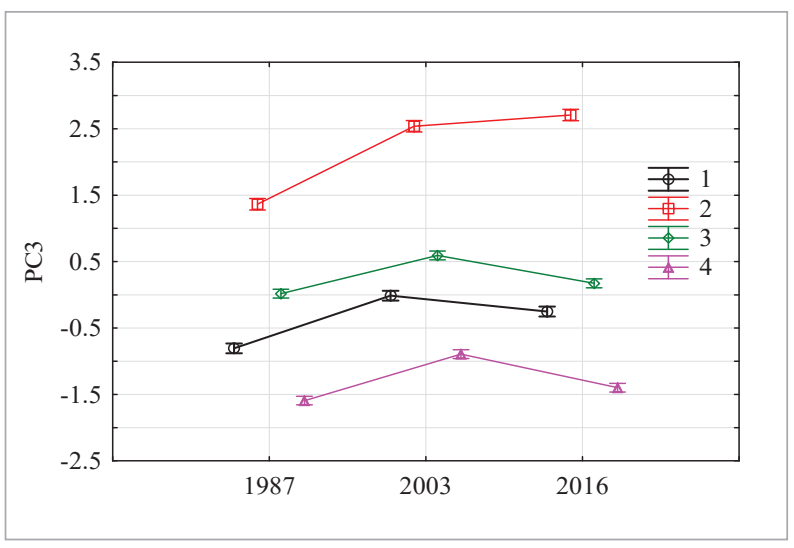

The most important factor in the PC3 variation is the type of technogenic edaphotop (i.e. $88.1 \%$ of the PC3 variation depends on this predictor). The PC3 indicates a relatively high content of hydrocarbonates in the technogenic edaphotop with a layer of black soil $50 \mathrm{~cm}$ (variant 2), while in other types the higher content of hydrocarbonates, chlorines and monovalent ions is observed at a higher $\mathrm{pH}$. In time, the PC3 values increase harmonicallyfor the technogenic edaphotop with a layer of black soil $50 \mathrm{~cm}$. However, for other types the variation with respect to time is not harmonic (Figure 8).

The PC 3 indicates the specific features of the profile salts distribution in the variant 2 which were formed at the moment of laying the technogenic edaphotops and the processes of salts redistribution in this variant during the study period (Figure 9).

Variant 2 is characterized by a higher content of calcium ions and lower values of $\mathrm{pH}$ and $\mathrm{HCO}_{3}{ }^{-}, \mathrm{Cl}^{-}$and $\mathrm{Na}^{+}+\mathrm{K}^{+}$ concentrations. During the overall time of observation, the aligned distribution of the appointed indices tends

Fig. 9

Profile distribution of PC3 values depending on the type of technogenic edaphotop in different periods of the study
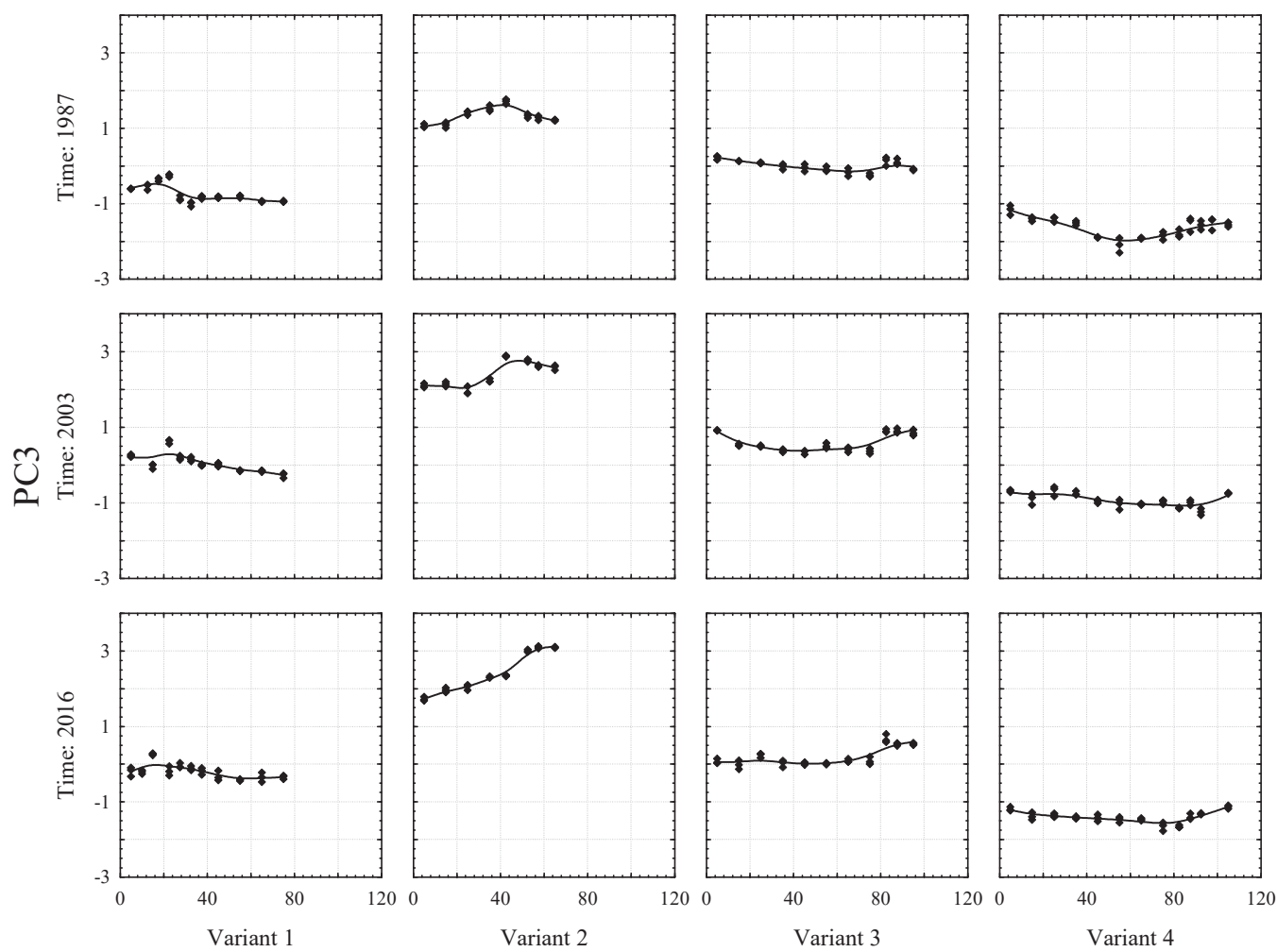

Depth 
towards those indicators, which are typical for other types of technogenic edaphotops mainly in the topsoil. The observed tendency of acquired characteristics is similar to other types of reclamation; this is in contrast to processes in the deeper layers where their dynamics slow down in the top soil of the profile in variant 2. However, the appointed features retain their stability over time.

\section{Conclusions}

It is established that the parameters of the layer-by-layer reactions variations, and the ion composition of

\section{References}

Baran S, Wójcikowska-Kapusta A, Żukowska G, Bik-Małodzińska M, Wesołowska-Dobruk S (2015). Influence of Sludge-Ash Composts on Some Properties of Reclaimed Land. Archives of Environmental Protection, Vol. 41, No. 2, pp. 82-88, ISSN 20834772. https://doi.org/10.1515/aep-2015-0022

Bellenfant G, Guezennec A, Bodénan F, D'Hugues P, Cassard D (2013). Re-processing of Mining Waste: Combining Environmental Management and Metal Recovery? Mine Closure, Cornwall, United Kingdom. pp.571-582.

Bender J (1983).Theoretical basis of technigenic landscape recultivation. Proceedings of the International Conference. Gyongyos. - P. 160-168.

Bian Zhengfu, Inyang Hilary I, Daniels John L, Otto Frank, Struthers Sue (2010). Environmental Issues From Coal Mining and Their Solutions. Mining Science and Technology, 20, 02150223. https://doi.org/10.1016/S1674-5264(09)60187-3

Chugh YP and Behum PT (2014). Coal Waste Management Practices in the USA: An Overview. Int J Coal Sci Technol, 1(2):163176. https://doi.org/10.1007/s40789-014-0023-4

Gharaibeh M.A., Nabil I. Eltaif N.I., Shra'a S.H. Desalination and Desodification Curves of Highly Saline-Sodic Soil Amended with Phosphoric Acid and by-Product Gypsum. International Journal of Environmental Science and Development, Vol. 3, No. 1, February 2012.:39-42. https://doi.org/10.7763/IJESD.2012.V3.184

Hayes SM, Root RA, Perdrial N, Maier R and Chorover J (2014). Surficial Weathering of Iron Sulfide Mine Tailings Under Semi-arid Climate. Geochim Cosmochim Acta. 141: 240-257. https://doi.org/10.1016/j.gca.2014.05.030

Hoff J and Kolff NA (2012). Hydraulic Fill Manual for Dredging and Reclamation Works. CRC Press/Balkema Taylor \& Francis Group, 642 pp, ISBN 978-0-415-69844-3. the aqueous extract along the reclaimed profiles of various models of technogenic edaphotop, gradually acquire a stable-equilibrium state of mineralization, both spatially and over time. This tendency reflects the characteristics of the zonal soils. It should be noted that the alkaline barrier is the main factor in both $\mathrm{pH}$ changes and in the surface salinization of reclaimed lands. The absence of a protective shielding layer of loess-like loam, for example, leads to rapid acidification of the soil solution due to the processes of chemical weathering of rocks at layers in contact with the mine dump

Huff GF (2014). Chemical Weathering of Smectitic Sulphide-Mineral-Bearing Unconsolidated Surficial Sediments in South-Central Alberta, Canada. Aquat Geochem, 20: 381. https://doi. org/10.1007/s10498-013-9223-6

José Roberto Pinto de Souza, Maria Fátima de Guimarães, Marcelo Marques Lopes Muller and Carlos Henrique dos Santos (2000). Morphological Alterations of Corn (Zea mays L.) Plants in Response to Aluminum Toxicity in the Soil. Brazilian Archives of Biology and Technology, vol.43 no.4, ISSN 16784324. https://doi.org/10.1590/S1516-89132000000400010

Kharytonov M (2007). Geochemical Assessment of Reclaimed Lands in the Mining Regions of Ukraine. NATO ARW Soil Chemical Pollution, Risk Assessment, Remediation and Security. Springer, Dordrecht/Netherlands, P. 57-60.

Kharytonov M.M. and Kroik A.A. (2011). Environmental Security of Solid Wastes in the Western Donbas Coal Mining Region, Ukraine. Environmental Security and Ecoterrorism, NATO Science for Peace and Security Series C: Environmental Security, H. Alpaset al. (eds.), p. 129-138. https://doi.org/10.1007/978-94-007-1235-5_10

Kharytonov MM and Yevgrashkina GP (2009). The Rocks Mass Properties and Moisture Transfer Process Assessment in the Reclaimed Lands//Sustainable exploitation of natural resources, Proceedings of the Third International Seminar. Ecomining-Europe in 21st Centure, Milos Island, Greece. - P.135-144.

Kharytonov MM, Sytnik SA, Vagner AV and Titarenko OV (2012). River pollution risk assessment in the south eastern part of Ukraine // Correlation between Human Factors and the Prevention of Disasters / Ed. by DL Barry, WG Coldewey, DWG Reimer, DV Rudakov. - Amsterdam: IOS Press. - P.159-169.

Konhke H (1950). The reclamation of coal mine spoils. Advances Agron, Vol. 2. - P. 317-349. 
Kostenko IV and Opanasenko NE (2005). Soil Formation on Sulfide Mine Dumps in Western Donets Basin upon their overgrowing. Eurasian Soil Science. V. 38, No 11. P. 1205-1212.

Kyncl M (2008). Opportunities for Water Treatment Sludge Reuse. GeoScience Engineering, Volume LIV, No.1, p. 11-22, ISSN $1802-5420$.

Larney FJ and Angers DA (2012). The Role of Organic Amendments in Soil Reclamation: A review. Canadian Journal of Soil Science, 92(1): 19-38. https://doi.org/10.4141/cjss2010-064

Lottermoser BG (2010). Mine Wastes: Characterization, Treatment and Environmental Impacts, 3rd Edition. Springer-Verlag, Berlin Heidelberg, 400 pp. https://doi.org/10.1007/978-3-642-12419-8

Malik A and Thapliyal A (2009). Eco-friendly Fly Ash Utilization: Potential for Land Application. Environmental Science and Technology, Volume 39, Issue 4, Pages 333-366. https://doi. org/10.1080/10643380701413690

Musslewhite B.D., Vinson J.R., Johnston C.R., Brown T.H, Wendt G.W., Vance G.F.Salinity and sodicity interactions of weathered minesoils in the four corners region. Proceedings America Society of Mining and Reclamation, 2006 pp 563-579. https://doi. org/10.21000/JASMR05010765

Nkongolo KK, Michael P, Theriault G, Narendrula R, Castilloux P, Kalubi KN, Beckett P and Spiers G (2016). Assessing Biological Impacts of Land Reclamation in a Mining Region in Canada: Effects of Dolomitic Lime Applications on Forest Ecosystems and Microbial Phospholipid Fatty Acid Signatures. Water, Air, \& Soil Pollution, 227:104. https://doi.org/10.1007/s11270-016-2803-5

Shengyin Wang, Xiaoyan Ren, Bingru Huang, Ge Wang, Peng Zhou and Yuan An (2016). Aluminium-induced Reduction of Plant Growth in Alfalfa (Medicago sativa) is Mediated by Interrupting Auxin Transport and Accumulation in Roots. Scientific Reports, 6: 30079. https://doi.org/10.1038/srep30079

Sheoran V., Sheoran A. S. and Poonia P. (2010). Soil Reclamation of Abandoned Mine Land by Revegetation: A Review. International
Journal of Soil, Sediment and Water, Vol. 3, Iss. 2, Article 13. Available at: http://scholarworks.umass.edu/intljssw/vol3/iss2/13

Silva S (2012). Aluminium Toxicity Targets in Plants. Journal of Botany, Volume 2012, Article ID 219462, 8 p. https://doi. org/10.1155/2012/219462

State Standard 26423-85 "Soils. Methods for determination of specific electric conductivity, $\mathrm{pH}$ and solid residue of water extract"

Tamanini CR, Motta ACV, Andreoli CV and Doetzer BH (2008). Land Reclamation Recovery With the Sewage Sludge Use. Brazilian Archives of Biology and Technology, Environmental Sciences, Vol.51, No.4, ISSN 1678-4324.https://doi.org/10.1590/ S1516-89132008000400023

Tarika 0 and Zabaluev V (2004). Mine land reclamation strategies in the Nikopol manganese ore basin (Central Steppe of Ukraine): Using replaced mining overburden in agriculture", Prec. of the 16th Ann. Conf. of the Society for Ecological Restoration, Victoria, BC, Canada.

Wiessner A, Mueller JA, Kuschk P, Kappelmeyer U, Kaestner M, Liu Y and Stottmeister U (2013). Environmental Pollution by Wastewater from Brown Coal Processing: a Remediation Case Study in Germany. Journal of Environmental Engineering and Landscape Management, ISSN 1648-6897 print/ISSN 18224199, online, Volume 00(00): 113. https://doi.org/10.3846/164 86897.2013.808640

Yevgrashkina GP, Rudakov DV and Kharytonov MM (2009). Environmental Protection Measure Assessment in Affected Area of Ponds Collecting Waste Mine-water in Western Donbass //Optimization of Disaster Forecasting and Prevention Measures in the Context of Human and Social Dynamics. I Apostol et al. (Eds.) IOS Press, Amsterdam - Berlin - Tokyo - Washington, DC. P.122-129. Zhenqi Hu, Shili Chu, Shan Zhao, J.R. Zhang and Z.J. Zhao (2004). Study on Soil Improvement for Reclaimed Subsided Land with Fly Ash and Organic Fertilizer. Proceedings America Society of Mining and Reclamation, pp 948-956. https://doi. org/10.21000/JASMR04010948 


\section{Vandenyje tirpių druskų vertikalios migracijos tendencijos analizè iš sąvartynų Ukrainoje}

\section{Iryna Klimkina}

Valstybine aukštoji mokykla "Nacionalinis kasybos universitetas", Ukraina

\section{Mykola Kharytonov}

Dnipropetrovsko valstybinis agrarinis ir ekonominis universitetas, Ukraina

\section{Oleksandr Zhukov}

Oles Honchar Dnipro nacionalinis universitetas, Ukraina

Siekiant išvystyti optimalią sąvartynu utilizavimo schemą, buvo ištirtas sąvartynu su skirtingais juodo dirvožemio masės sluoksniais, tiek su ir be lakštinio priemolio apsauginio sluoksnio. Pagrindinès komponentu analizès buvo atliktos, siekiant atskleisti dugninės aukštumos migracijos i atsinaujinančiu anglies paviršių dèsningumus. Fizinių ir cheminių duomenų sluoksnio pokyčiai dirvožemio vandens ekstraktuose (būtent, pH, bendras druskingumas ir bikarbonatų, chloridų, sulfatu, kalcio, magnio, natrio ir kalio koncentracijos), gautu 1987 m. 2003 ir 2016 m. kartu su jvairiais technogeninio edaphoto modelio regeneruotais profiliais, palaipsniui igyja stabilios pusiausvyros mineralizacijos būklè. Šarminis barjeras yra pagrindinis veiksnys, lemiantis pH pokyčius ir regeneruotos žemės profiliu šalinimą.

Raktiniai žodžiai: sąvartynai, vandenyje tirpių druskų migracija, dirvožemis. 